\title{
A hólyagkontraktilitási index meghatározásának fontossága a csökkent hólyagmúködés kezelésében
}

\author{
Ghirca Maria Veronica dr. ${ }^{1}$ - Chibelean Călin dr. ${ }^{2}$ \\ Frunda E. Anna ${ }^{3}$ - Mártha Orsolya dr. ${ }^{1}$ \\ University of Medicine and Pharmacy of Tîrgu Mureş, ${ }^{1}$ Clinic of Urology, \\ ${ }^{2}$ Mureş County Hospital, Tîrgu Mureş, Románia \\ ${ }^{3}$ University of Medicine and Pharmacy of Tîrgu Mureş, Románia
}

\begin{abstract}
Célkitüzés: A hólyagkontraktilitási index (BCI) fontosságának felmérése a csökkent hólyagmúködés kezelésében. Betegek és módszer: Retrospektív tanulmányunkban 2013. január és 2016. szeptember közötti, detrusor-alulmúködéssel $(\mathrm{BCI}<100)$ kórismézett beteg adatait dolgoztuk fel $(\mathrm{BCI}=\mathrm{Pdet} \mathrm{Qmax}+5 \mathrm{Qmax})$.

Eredmények: A tanulmányozott betegek (férfi 38, nő 53) esetében a BCI átlagértéke 55 volt (17-110), urodinámiás vonatkozásban: átlag-Qmax $7 \mathrm{ml} / \mathrm{s}$, átlag-Pdet $14 \mathrm{H}_{2} \mathrm{O}-\mathrm{cm}$. A BCI csökkenő tendenciát mutat az életkor elórehaladtával, valamint összefüggés mutatható ki a BCI, a diabetes $(\mathrm{p}=0,003)$, illetve a neurológiai betegségek $(\mathrm{p}=$ $0,015)$ között.

Következtetések: A csökkent hólyagmúködés kórismézése igazi kihívás az urológus számára, az urodinámiás vizsgálatok (a residuum értéke, Qmax, PdetQmax) és a BCI értéke nagyban elősegítik a megfelelő kezelési terv felállítását. Orv Hetil. 2017; 158(31): 1222-1227.
\end{abstract}

Kulcsszavak: urodinámiás, detrusor-alulmúködés, hólyagkontraktilitási index

\section{The importance of Bladder Contractility Index in the management of underactive bladder}

\begin{abstract}
Aim: To evaluate the importance of BCI in the management of underactive bladder (UB).
Material and method: A retrospective study over a period of 3 years and 9 months (January 2013-September 2016) in Mureş County Hospital, Clinic of Urology, including 91 patients. Detrusor underactivity was defined by BCI less than 100 using the formula: PdetQmax+5Qmax.

Results: The median of Qmax value was $7 \mathrm{ml} / \mathrm{s}$ and the median value of Pdet was $14 \mathrm{~cm} \mathrm{H}_{2} \mathrm{O}$. The median value of BCI was 55 with extremities between 17 and 110 . BCI tends to decrease with age and there is a relation between value of BCI and diabetes $(\mathrm{p}=0,003)$ and neurological diseases $(\mathrm{p}=0,015)$.

Conclusions: The UB diagnosis represents a real challenge for the urologist, so that, urodynamical findings such as absence of bladder obstruction, post-void residual urine, Qmax, together with BCI value, helps in setting the proper management.
\end{abstract}

Keywords: urodynamic, BCI, underactive bladder

Ghirca MV, Chibelean C, Frunda EA, Mártha O. [The importance of Bladder Contractility Index in the management of underactive bladder]. Orv Hetil. 2017; 158(31): 1222-1227.

(Beérkezett: 2017. április 7.; elfogadva: 2017. június 8.) 


\section{Rövidítések}

BCI = (Bladder Contractility Index $)$ hólyag-összehúzódási index; $\mathrm{DU}=$ (detrusor underactivity) detrusor-alulmúködés; ICS $=($ International Continence Society $)$ Nemzetközi Kontinencia Társaság; LUTS $=$ (lower urinary tract symptoms) alsó húgyúti tünetek; Pdet $=$ (detrusor pressure $)$ detrusornyomás; $\mathrm{PFS}=$ (pressure flow study) nyomásáramlás-meghatározás; PVR = (post-void residual urine) residualis vizeletmennyiség; Qmax $=$ (peak flow rate) maximális áramlás; $\mathrm{SD}=$ standard deviáció; $\mathrm{UAB}=$ (underactive bladder $)$ alulmúködő hólyag

A hipoaktív hólyag (underactive bladder - UAB) egy összetett klinikai rendellenesség, amely az orvosi irodalomban nem igazán kutatott terület, így nem annyira közismert. A hipoaktív hólyag legfontosabb jellemzője a hólyag detrusor izmának alulmúködése, aminek következtében hólyagürüléssel kapcsolatos tünetek jelentkeznek [1].

A Nemzetközi Kontinencia Társaság (ICS) definíciója alapján a hipoaktív hólyag (hólyag-alulmúködés) nem más, mint a detrusor izom nem kellő erejű és idejű öszszehúzódása, a hólyag lassú és/vagy nem teljes kiürülése [2].

A betegek életminőségét tekintve ez kiemelkedő problémát jelent: befolyásolja úgy a szociális, fizikai, mint a szexuális életüket, ezáltal szakorvosi ellátásra kényszerülnek [3].

Előfordulása egyaránt érinti a nőket és a férfiakat, az alsó húgyutak ürüléssel kapcsolatos tüneteinek (LUTS) kiemelkedő oka, amely jelentősen befolyásolja az idős lakosság számottevő részét [3-6]. Az alsó húgyutak ürüléssel kapcsolatos tünetei közül legfontosabbak a következők: csökkent, gyengült, megszakadó vizeletsugár, nehezített, habozó vizeletindítás, dysuria, nem teljes ürülés érzete, utócsepegés, illetve visszatérő húgyúti fertőzések [7].

A detrusor izom alulmúködésének etiológiája még nem egyértelmú, de kutatások alapján a következő okokra lehet gondolni $[3,8,9]$ :

- idiopathiás okok: természetes öregedés, ismeretlen okok (fóleg fiataloknál);

- neurológiai okok: Parkinson-kór, sclerosis multiplex, cukorbetegség, Guillain-Barré-szindróma, gerincsérv, gerincvelő gyulladásai, veleszületett gerincvelő-betegségek;

- myogen okok: a hólyagszájadék különböző okok miatti obstrukciója, cukorbetegség;

- iatrogén okok: kismedence mútétei, radikális prostatectomia, radikális hysterectomia stb.

Ami a kórismét illeti, az urodinámiás vizsgálatoknak kiemelkedő szerepe van (vizeletáramlás, nyomás-áramlás vizsgálat), ugyanakkor fontos a jó anamnézis, elősegító tényezők feltérképezése, a pontos tünettan, a residualis vizeletmennyiség ultrahangos vizsgálattal történő meghatározása (PVR), a vizelési napló, illetve a vizelet vizsgálata [1]. Egy nem kellőképpen múködő detrusor esetében számos paraméter áll a rendelkezésünkre, amelyek segítségével megállapíthatjuk a hipoaktivitás súlyosságát. A fentiek közül a nyomás-áramlás vizsgálat során nyert adatok segítségével kiszámítható a hólyag-összehúzódási index (Bladder Contractility Index - BCI) [1, 8]. Vizeletelfolyási akadály kizárása esetében a BCI 100 alatti értéke eleget tesz a hipoaktív hólyag kritériumának [8].

\section{Célkitüzés}

Dolgozatunk célja összefoglalni a hipoaktív hólyag leggyakoribb tüneteit, okait, kórismézési lehetőségeit, illetve kiemelni a BCI fontosságát a betegség helyes kezelése, illetve utánkövetése szempontjából.

\section{Betegek és módszer}

A marosvásárhelyi Urológiai Klinikán 2013. január és 2016. szeptember között 125 urodinámiás beteg kivizsgálását végeztük. Retrospektív tanulmányunkban hipoaktív hólyaggal kórismézett 91 beteg $(72,8 \%)$ adatait dolgoztuk fel.

A tanulmány alapjául szolgáló vizsgálati protokoll a következő kritériumokat foglalta magába:

- Ürüléssel kapcsolatos alsó húgyúti panaszok.

- UAB rizikófaktorainak azonosítása (előrehaladott életkor, idegrendszeri betegségek, gyógyszerek, cukorbetegség, sebészi beavatkozások a kismedence szintjén stb.).

- Fizikális vizsgálat.

- Hasi ultrahangvizsgálat, postmictionális residualisvizelet-meghatározás.

- Vizeletvizsgálat, esetenként bakteriális leoltás.

- Nőgyógyászati és neurológiai vizsgálatok szükség szerint.

- Urodinámiás vizsgálatok (vizeletáramlás-meghatározás, nyomás-áramlás vizsgálat: $\operatorname{Pdet}<30 \mathrm{H}_{2} \mathrm{O}-\mathrm{cm}$ ).

- BCI értéke <100 (BCI = PdetQmax (a detrusor nyomásértéke csúcsáramláskor) + 5xQmax).

Azokban az esetekben, ahol nem tudtuk kizárni az alsó húgyúti obstrukciót a fenti vizsgálati prokoll alapján, uretroszkópiát, uretrocisztoszkópiát vagy radiológiai kivizsgálásokat végeztünk. Így tanulmányunkból kizártuk a nyilvánvaló alsó húgyúti obstrukciós betegeket.

\section{Eredmények}

A fenti kritériumok alapján tanulmányunkba 91 beteget vontunk be, 53 nöt $(58,2 \%)$, illetve 38 férfit $(41,8 \%)$. Detrusor-alulmúködést leggyakrabban a 60-79 éves betegeknél mutattunk ki (46 eset), a 40-49 éves korosztályban 17 esetben, illetve a 20-39 éves korosztályban 15 esetben fordult elő.

A betegek átlagéletkora 58,6 év (SD - standard deviáció $\pm 14,06)$, az értékek 27 évtől 82 évig jelennek meg (1. ábra). 
Esetszám

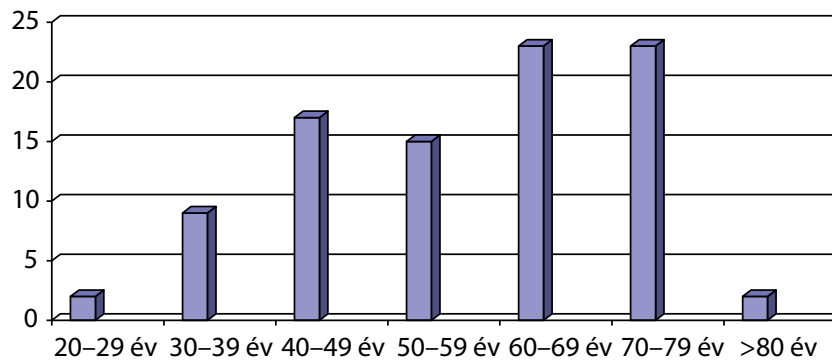

1. ábra A hipoaktív hólyag előfordulása az életkor függvényében

A hipoaktív hólyagú betegeknél a leggyakrabban a következő tünetek fordultak elő: dysuria 65 esetben $(71,4 \%)$, gyenge vagy megszakított sugár 60 esetben $(65,9 \%)$, pollakisuria 63 esetben $(69,2 \%)$, nocturia 40 esetben $(44 \%)$, vizelési késztetés 25 esetben $(27,5 \%)$, vizelési hezitáció 46 esetben (50,5\%), a hólyag nem teljes ürülésének érzete 40 esetben $(44 \%)$ (2. ábra). Az alsó húgyúti tünetek egyedül vagy társultan jelentkeztek. A tünetmentes betegeknél nem végeztünk urodinamikai vizsgálatokat.

Kórelőzmények tekintetében a következő elősegítő tényezőket tudtuk azonosítani: diabetes 34 esetben $(37,4 \%)$, kismedencét érintő sebészeti beavatkozások (hysterectomia, végbélmúttétek, stresszinkontinencia miatti mútétek) 33 esetben (36,3\%), pszichotrop medikáció 17 esetben $(18,7 \%)$, neurológiai betegségek (Parkinson-kór, sclerosis multiplex, gerincsérv, gerincvelő betegségei) 30 esetben (33\%), kor (idősebb mint 70 év) 25 esetben (3. ábra). A BMI (body mass index) értéke a betegek többségénél magas volt (25-29,9), a BMI-érté-
1. táblázat |A residualis vizeletmennyiség változása

\begin{tabular}{llllll}
\hline $\begin{array}{l}\text { Residualis } \\
\text { vizeletmennyiség } \\
(\mathrm{ml})\end{array}$ & $\begin{array}{l}\text { Abszolút } \\
\text { gyakoriság } \\
\text { (beteg- } \\
\text { szám) }\end{array}$ & $\begin{array}{l}\text { Relatív } \\
\text { gyakori- } \\
\text { ság }\end{array}$ & $\begin{array}{l}\text { Érvényes } \\
\text { relatív } \\
\text { gyakoriság }\end{array}$ & $\begin{array}{l}\text { Kumulatív } \\
\text { relatív } \\
\text { gyakoriság }\end{array}$ \\
\hline \multirow{2}{*}{$\begin{array}{l}\text { Érvényes } \\
\text { adat }\end{array}$} & $0-100$ & 34 & 18,7 & 18,7 & 18,7 \\
& $100-200$ & 24 & 26,4 & 26,4 & 82,4 \\
& 200 felett & 16 & 17,6 & 17,6 & 100,0 \\
\hline & Összes & 91 & 100,0 & 100,0 & \\
\hline
\end{tabular}

kek átlaga 26,78 (SD - standard deviáció $\pm 3,6$ ), értékek 18,4-től 37-ig.

A vizelet bakteriológiai leoltása 48 betegnél mutatott ki fertőzést, ezekben az esetekben célzott antibiotikus kezelést végeztünk.

Hasi ultrahangvizsgálat 64 esetben nem teljes vizeleti retenciót $(69,2 \%), 17$ esetben retenciómentes hólyagot $(18,7 \%)$ mutatott ki, 10 esetben ( $11 \%)$ pedig teljes vizeletretenciót kórisméztünk. A visszamaradó vizelet menynyiségét milliliterben $(\mathrm{ml})$ határoztuk meg, az esetek többségében kevesebb mint $100 \mathrm{ml}$ volt (34 eset), 16 esetben nagy mennyiségü residualis volument mértünk, ezekben az esetekben nagy hólyagkapacitást észleltünk (400 ml felettit) (1. táblázat). Az átlag residualis vizeletmennyiség $153,74 \mathrm{ml}(\mathrm{SD}-$ standard deviáció $\pm 87,31)$, értékek $30 \mathrm{ml}$-től $400 \mathrm{ml}$-ig.

Urodinamikai meghatározásokat végeztünk minden esetben (vizeletáramlás-meghatározás, nyomás-áramlás vizsgálat). Teljes vizeletretencióval kórismézett betegek (összesen 10 eset) közül négy esetben nem sikerült nyomás-áramlás vizsgálatot végezni (nem tudtak spontán

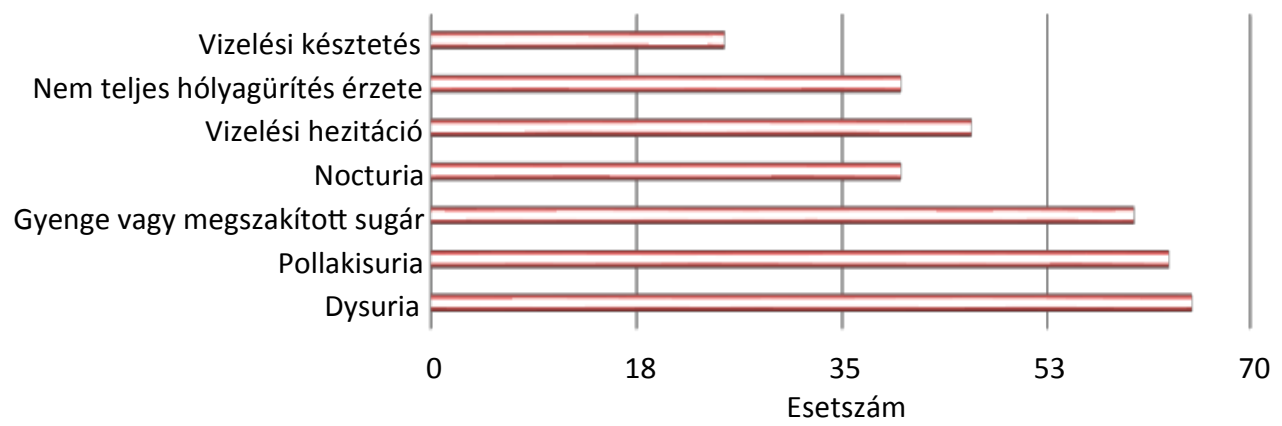

2. ábra | A hipoaktív hólyag tüneteinek előfordulása

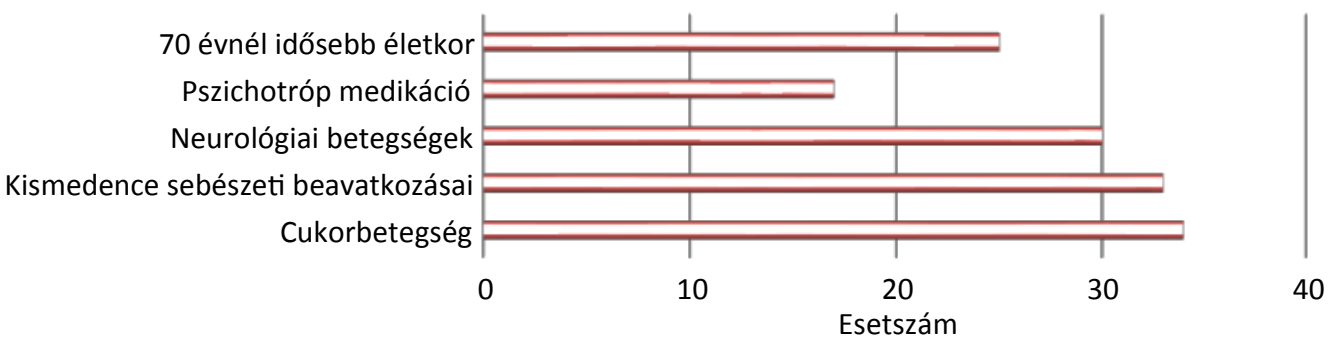

3. ábra | Hipoaktív hólyag - elősegítő tényezők 
2. táblázat |A Qmax értéke hipoaktív hólyagú betegeknél

\begin{tabular}{|c|c|c|c|c|c|}
\hline \multicolumn{2}{|c|}{$\mathrm{Qmax}(\mathrm{ml} / \mathrm{s})$} & \multirow{2}{*}{$\begin{array}{l}\text { Abszolút } \\
\text { gyakoriság } \\
\text { (betegszám) }\end{array}$} & \multirow{2}{*}{$\begin{array}{l}\begin{array}{l}\text { Relatív } \\
\text { gyakoriság }\end{array} \\
83,5\end{array}$} & \multirow{2}{*}{$\begin{array}{l}\begin{array}{l}\text { Érvényes } \\
\text { relatív } \\
\text { gyakoriság }\end{array} \\
83,5\end{array}$} & \multirow{2}{*}{$\begin{array}{l}\begin{array}{l}\text { Kumulatív } \\
\text { relatív } \\
\text { gyakoriság }\end{array} \\
83,5\end{array}$} \\
\hline Érvényes & $<15$ & & & & \\
\hline adat & $>15$ & 15 & 16,5 & 16,5 & 100,0 \\
\hline & Összes & 87 & 100,0 & 100,0 & \\
\hline
\end{tabular}

3. táblázat |A BCI értéke hipoaktív hólyagú betegeknél

\begin{tabular}{llllll}
\hline BCI értéke & $\begin{array}{l}\text { Abszolút } \\
\text { gyakoriság } \\
\text { (beteg- } \\
\text { szám) }\end{array}$ & $\begin{array}{l}\text { Relatív } \\
\text { gyakoriság }\end{array}$ & $\begin{array}{l}\text { Érvényes } \\
\text { relatív } \\
\text { gyakoriság }\end{array}$ & $\begin{array}{l}\text { Kumulatív } \\
\text { relatív } \\
\text { gyakoriság }\end{array}$ \\
\hline $\begin{array}{l}\text { Érvényes } \\
\text { adat }\end{array}$ & $<100$ & 83 & 91,2 & 91,2 & 95,6 \\
\hline & $>100$ & 4 & 4,4 & 4,4 & 100,0 \\
\hline
\end{tabular}

4. táblázat |A hólyag-összehúzódási index és a detrusor-hipoaktivitás rizikófaktorai közti összefüggés

Többváltozós regresszió

\begin{tabular}{|c|c|c|c|c|}
\hline Függő változó & Hólyag-össz & úzódási in & & \\
\hline Független változók & Együttható & $\begin{array}{l}\text { Standard } \\
\text { hiba }\end{array}$ & $\mathrm{t}$ & $\mathrm{p}$ \\
\hline $\begin{array}{l}\text { Neurológiai } \\
\text { betegségek }\end{array}$ & $-9,5988$ & 5,2166 & $-1,840$ & 0,0425 \\
\hline Cukorbetegség & $-13,7439$ & 5,0970 & $-2,696$ & 0,0085 \\
\hline Kismedencei mütétek & 1,5780 & 5,0508 & 0,312 & 0,7555 \\
\hline $\begin{array}{l}\text { Pszichiátriai } \\
\text { betegségek }\end{array}$ & $-6,4702$ & 6,4798 & $-0,999$ & 0,3210 \\
\hline Életkor & $-3,4005$ & 5,9200 & $-0,574$ & 0,5673 \\
\hline
\end{tabular}

5. táblázat $\mid$ A hólyag-összehúzódási index és a Qmax, illetve Pdet közötti összefüggés

Többváltozós regresszió

\begin{tabular}{|c|c|c|c|c|}
\hline Függő változó & \multicolumn{4}{|c|}{ Hólyag-összehúzódási index } \\
\hline $\begin{array}{l}\text { Független } \\
\text { változók }\end{array}$ & Együttható & Standard hiba & $\mathrm{t}$ & $\mathrm{p}$ \\
\hline Pdet & 0,9919 & 0,03845 & 25,797 & $<0,0001$ \\
\hline Qmax & 4,9291 & 0,04310 & 114,363 & $<0,0001$ \\
\hline
\end{tabular}

vizelni a feltöltést követően), így őket nem vettük figyelembe a statisztikai felmérésekben.

$\mathrm{Az}$ urodinamikai vizsgálatok a következő adatokat szolgáltatták: normális Qmax (csúcsáramlás) 15 esetben, alacsony csúcsáramlás 72 esetben (2. táblázat). A csúcsáramlás középértéke $7 \mathrm{ml} / \mathrm{s}$, az értékek $2 \mathrm{ml} / \mathrm{s}$ és $19 \mathrm{ml} / \mathrm{s}$ között mozogtak. Nyomás-áramlás vizsgálatok során a $30 \mathrm{H}_{2} \mathrm{O}-\mathrm{cm}$ (Pdet) alatti értékeket alacsony nyo- másnak tekintettük, átlagérték $14 \mathrm{H}_{2} \mathrm{O}-\mathrm{cm}, 7-30 \mathrm{H}_{2} \mathrm{O}$ cm közötti limitekkel.

A BCI-t (hólyag-összehúzódási indexet) a következő képlettel határoztuk meg:

$\mathrm{BCI}=$ Pdet, $\mathrm{Qmax}+5 \mathrm{xQmax}$.

A detrusor-hipoaktivitást, -alulmúködést 100 alatti BCI esetében kórisméztük. Tanulmányunkban a BCI 17 és 110 között mozgott, 55 átlagértékkel (3. táblázat). Mann-Whitney-teszt és többszörös regresszió elemezte a BCI és a detrusor hipoaktivitása közötti összefüggést (előrehaladott kor, elmegyógyászati, neurológiai betegségek, kismedencei sebészeti beavatkozások és cukorbetegség). A betegek életkorát tekintve nincs statisztikai összefüggés a BCI-vel $(\mathrm{p}=0,29)$, viszont a BCI értéke a kor előrehaladtával csökken (4. ábra).

Statisztikailag szignifikáns összefüggést észleltünk a BCI és a cukorbetegség között $(\mathrm{p}=0,003)$, valamint a BCI és neurológiai patológia között $(\mathrm{p}=0,015)$ (4. táblázat).

A Spearman-teszt összefüggést mutat a BCI-érték és a residualis volumen (PVR) között, $\mathrm{p}<0,0001$. A BCI-érték alacsonyabb azoknál a betegeknél, akiknél a residualis volumen számottevő (5. ábra).

A BCI, a Qmax és a Pdet közötti összefüggés egy többváltozós logisztikai regresszió segítségével mutatható ki, ahol a függő változó a $\mathrm{BCI}$, a független változó a Qmax és a Pdet. Ebben az összefüggésben azt észleltük, hogy a BCI értékét két független változó befolyásolja

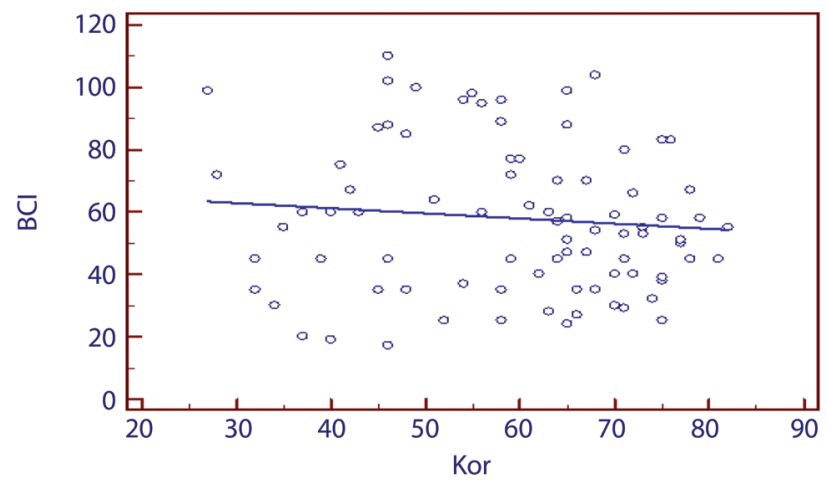

4. ábra

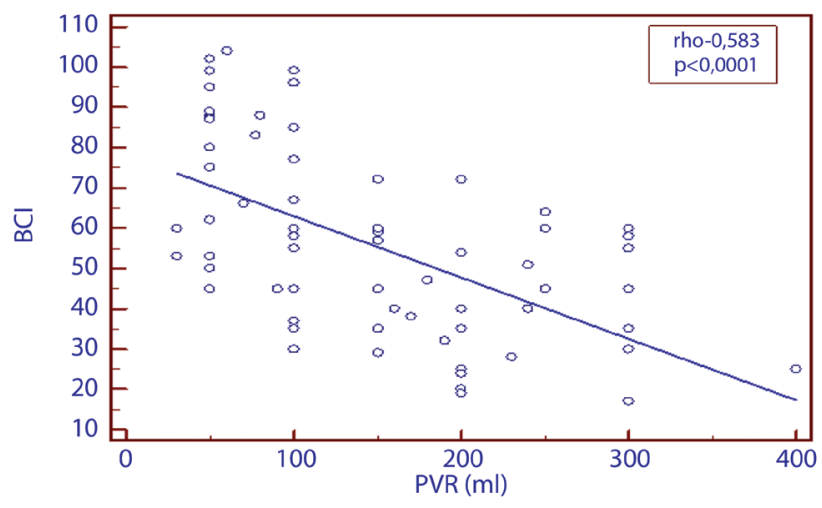

5. ábra | A BCI értéke és a residualis volumen közötti összefüggés 
$(\mathrm{p}=0,0001)$. A Spearman-teszt szoros összefüggést mutatott a BCI értéke és a Qmax értéke között $(\mathrm{p}<0,0001)$, viszont nem mutatott összefüggést a Pdet értékével $(\mathrm{p}=$ 0,25) (5. táblázat).

A Spearman-teszt nem mutatott összefüggést a Qmax és Pdet értéke között sem ( $\mathrm{p}=0,81)$.

\section{Megbeszélés}

A hipoaktív hólyag egy kevésbé ismert patológia, Osman és mtsai [8] egy 2014-es tanulmányban incidenciáját az 50 év alatti férfiak esetében mintegy 9-28\%-ban határozták meg, idősebb korban (70 éves kor felett) előfordulása $48 \%$-ra nő. Előfordulása nóknél is a korral párhuzamosan emelkedik, 12\%-ról 45\%-ra [10].

Tanulmányunkban a leginkább érintett korosztály a 60 év feletti volt $(52,74 \%)$. Fiatalkorban (40 év alatt) a betegség 12,08\%-ban fordul elő. Az átlagéletkor 58,58 év volt egy 14,06-os standard deviációval.

Abrams szerint, ha a hólyagkontraktilitási index nagyobb, mint 150, akkor erős izomkontrakcióról, 100150 között normális kontrakcióról, míg 100 alatt gyenge kontrakcióról beszélünk [2]. Jeong és mtsai egy 632 betegen végzett tanulmány alapján megállapították, hogy a BCI értéke 100 alatti volt a 65 év feletti betegek mintegy 40,2\%-ában [11]. A mi tanulmányunkban a BCI átlagértéke 55 volt, 17 és 110 közötti limitekkel. Mindössze négy beteg esetében mértünk 100-nál nagyobb BCI-értéket $(4,4 \%)$, normális Qmax $(15 \mathrm{ml} / \mathrm{s}$ feletti), illetve alacsonyabb Pdet $\left(30 \mathrm{H}_{2} \mathrm{O}\right.$-cm-nél alacsonyabb) értékek esetében.

A hipoaktív hólyag okozta tünetek tekintetében Hoag és Gani tanulmányukban 79 beteget vizsgáltak meg, 63,3\%-uknál jelentkezett sürgősségi vizelési inger, 61\%nak gyenge volt a vizeletsugara, 57\%-ban feszítő vizelési inger, 48\%-ban nocturia jelentkezett [1]. Gammie és mtsai tanulmányukban rávilágítottak arra, hogy a hipoaktív hólyag szindrómában szenvedő betegeknél gyakrabban fordul elő a szaggatott vizeletsugár, vizelési hezitáció, nem teljes hólyagürítés érzete, tapintható hólyag, mint azoknál a betegeknél, akiknél a nyomás-áramlás normális [12]. A mi tanulmányunkban a leggyakrabban előforduló tünetek a következők voltak: dysuria $(71,4 \%)$, megszakított vizeletsugár $(65,9 \%)$, gyakori vizelés $(69,2 \%)$, nem teljes hólyagürítés érzete $(43,9 \%)$. A tanulmányban szereplő összes betegnél jelen volt egy vagy több alsó húgyúti tünet. Nyomásáramlás-meghatározást tünetmentes betegeknél nem végeztünk. A használt képlet alapján erős korreláció mutatható ki a BCI és a Qmax között. A Qmax értéke befolyásolja a BCI értékét még akkor is, ha hasonló tüneteket mutat. Nem találtunk eltérést hasonló tünetekkel rendelkező betegek és a BCI értéke között. A BCI értéke az urodinamikai paraméterek eredményétól függ.

A hipoaktív hólyag leggyakoribb okai: életkor előrehaladása, cukorbetegség, neurológiai patológia, kismedencei sebészeti beavatkozások stb. Az öregedés a detrusor izom aktivitásának hanyatlásával hozható összefüggésbe, bár más is befolyásolja az izom gyengülését, mint a myogen és neurogen faktorok [13]. Egy 2010-ben végzett tanulmányban Smith rávilágított arra, hogy a funkcionális és szerkezeti változások befolyással vannak a hólyag afferens funkciójára, így annak kiürülésére is [6]. Jeong és mtsai 1179, 65 év feletti betegen végzett tanulmányukban rávilágítottak a hólyag-hipoaktivitás és öregedés közti összefüggésekre. Adataik szerint az alulmúködés 70 év feletti betegek esetében volt a leggyakoribb [11]. Tanulmányunk adatai egyértelmúen alátámasztják a hólyag-alulmúködés és a kor összefüggését, ugyanakkor azt is bizonyítják, hogy a kor előrehaladtával a hólyagkontraktilitási index is csökken.

Idegi károsodás - mint például autonóm neuropathia - az efferens idegi pályák zavarát okozhatja, ami gyenge vagy hiányzó detrusormúködést eredményezhet [8]. Cukorbetegség során kialakult neuropathia a vizelési reflex csökkenéséhez, illetve megszűnéséhez vezethet [14]. Tanulmányunkban egyértelmú összefüggést mutattunk ki a BCI csökkenése és neurológiai kórképek, diabetes között $(\mathrm{p}=0,042, \mathrm{p}=0,008)$.

A residualis vizeletmennyiség $40 \%$ feletti értéke potenciális jelzője lehet az ingerszegény detrusor izomnak [8]. Értekezésünkben a betegek 69,2\%-ában mutattunk ki residuumot, átlagérték: 153,74 ml (SD - standard deviáció $\pm 87,31)$. Statisztikai analízisek szoros kapcsolatot véltek felfedezni a magas BCI-szint (100 feletti) és PCI között, minél alacsonyabb a BCI értéke, annál magasabb a PCI.

Az orvosi irodalom adatai szerint az alacsony vizeletáramlás a betegek 10-20\%-ában hólyag-hipoaktivitással jár együtt. Tanulmányunkban az esetek többségében alacsony volt a Qmax értéke (átlag $7 \mathrm{ml} / \mathrm{s}$ ) [15, 16]. Az invazívnak tartott nyomás-áramlás vizsgálat az egyetlen módszer, amellyel a detrusor izom kontraktilitását mérni lehet [8]. Adataink azt mutatták, hogy a Qmax és a Pdet értéke befolyásolja a BCI-t $(\mathrm{p}<0,0001)$, a Spearmanteszt pedig szoros összefüggést észlelt a BCI-érték és a Qmax értéke között ( $\mathrm{p}<0,0001)$. A Qmax-értéknek így megnő a fontossága a BCI meghatározásában. Egy alacsony Qmax-érték nem jelent minden esetben alulmúködést, illetve egy normális érték nem zárja ki a hipoaktivitást. Ez a hipotézis megnöveli a BCI meghatározásának fontosságát. Egyes esetekben, ahol a Pdet értéke kisebb, mint $30 \mathrm{H}_{2} \mathrm{O}-\mathrm{cm}$, a Qmax értéke lehet normális (>15 $\mathrm{ml} / \mathrm{s})$ a hasprés miatt. Ezen esetekben a BCI lehet normális értékü (a Qmax értéke növeli a BCI értékét a képlet szerint), így létezhet olyan eset, ahol a betegek hasonló tünetekkel, de különböző BCI-értékkel rendelkeznek.

\section{Következtetések}

A hipoaktív hólyag egy összetett, növekedő tendenciát mutató alsó húgyúti patológia. Az előrehaladott életkor, a cukorbetegség, neurológiai patológia megnövelik a betegség előfordulásának lehetőségét. A kórisme szem- 
pontjából az urodinamikai kivizsgálások nyújtják a legtöbb információt. A BCI, hólyagkontraktilitási index egy egyszerü, könnyen kiszámítható adat. Egy 100 alatti BCI, a subvesicalis obstrukció kizárása esetén a detrusor csökkent aktivitását kórjelzi. Úgy gondoljuk, hogy az ezen paraméter klinikai gyakorlatban való alkalmazása nagymértékben megkönnyítené a hólyag-hipoaktivitás kórismézését.

Anyagi támogatás: A közlemény megírása anyagi támogatásban nem részesült.

Szerzői munkamegosztás: G. M. V.: Urodinamikai vizsgálatok elvégzése, adatok feldolgozása, statisztikai számítások, szerkesztés. C. C: Adatok kiértékelése. F. E. A.: Adatok feldolgozása, szerkesztés, angol összefoglaló szerkesztése. M. O.: Urodinamikai vizsgálatok elvégzése, adatok feldolgozása, mentorálás, javítás. A cikk végleges változatát valamennyi szerző elolvasta és jóváhagyta.

Érdekeltségek: A szerzőknek nincsenek érdekeltségeik.

\section{Irodalom}

[1] Hoag N, Gani J. Underactive bladder: Clinical features, urodynamic parameters and treatment. Int Neurourol J. 2015; 19 : 185-189.

[2] Abrams P, Cardozo L, Fall M, et al. The standardization of terminology of lower urinary tract function: report from the Standardization Sub-committee of the International Continence Society. Neurourol Urodyn. 2002; 21: 167-178.

[3] Wein AJ. Pathophysiology and classification of lower urinary tract dysfunctions: Overview. In: Wein AJ. (ed.) Campbell-Walsh Urology. 10th edition. Elsevier Saunders, Philadelphia, PA, 2011; pp. 1834-1846.
[4] Malik RD, Cohn JA, Bales GT. Urinary retention in elderly women: diagnosis and management. Curr Urol Rep. 2014; 15: 454.

[5] Nitti VW. Urodynamic and videourodynamic evolution of lower urinary tract. In: Wein AJ. (ed.) Campbell-Walsh Urology. 10th edition. Elsevier Saunders, Philadelphia, PA, 2012; pp. 17181742 .

[6] Smith PP. Ageing and the underactive detrusor: a failure of activity or activation? Neurourol Urodyn. 2010; 29: 408-412.

[7] Miyasato M, Yoshimura N, Chancellor MB. The other bladder syndrome: Underactive bladder. Rev Urol. 2013; 15: 11-22.

[8] Osman NI, Chapple C, Abrams P, et al. Detrusor underactivity and the underactive bladder: a new clinical entity? A review of current terminology, definitions, epidemiology, aetiology and diagnosis. Eur Urol. 2014; 65: 389-398.

[9] Anderson KE. Bladder underactivity. Eur Urol. 2014; 65: 399401.

[10] Chancellor MB, Blaivas JG, Kaplan SA, et al. Bladder outlet obstruction versus impaired detrusor contractility: the role of outflow. J. Urol. 1991; 145: 810-812.

[11] Jeong SJ, Kim HJ, Lee YJ, et al. Prevalence and clinical features of detrusor underactivity among elderly with lower urinary tract symptoms: a comparison between men and women. Korean J Urol. 2012; 53: 342-348.

[12] Gammie A, Kaper M, Dorrepaal C, et al. Signs and symptoms of detrusor underactivity: an analysis of clinical presentation and urodynamic tests from a large group of patients undergoing pressure flow studies. Eur Urol. 2016; 69: 361-369.

[13] Van Koeveringe GA, Vahabi B, Andersson KE, et al. Detrusor underactivity: a plea for new approaches to a common bladder dysfunction. Neurourol Urodyn. 2011; 30: 723-728.

[14] Suskind AM, Smith PP. A new look at detrusor underactivity: impaired contractility versus afferent dysfunctions. Curr Urol Rep. 2009 ; 10: 347-351.

[15] Abrams P. Urodynamics. 3rd ed. Springer, London, UK, 2006.

[16] Abrams P, Griffiths DJ. The assessment of prostatic obstruction from urodynamic measurements and from residual urine. $\mathrm{Br} \mathrm{J}$ Urol. 1979; 51: 129-134.

(Frunda E. Anna, e-mail: frunda.anna@gmail.com)

\section{Tisztelt Szerzőink, Olvasóink!}

Az Orvosi Hetilapban megjelenő/megjelent közlemények elérhetőségére több lehetőség kínálkozik.

Rendelhető különlenyomat, melynek áráról bővebben a www.akkrt.hu honlapon (Folyóirat Szerzőknek, Különlenyomat menüpont alatt) vagy Szerkesztöségünkben tájékozódhatnak.

A közlemények megvásárolhatók pdf-formátumban is, illetve igényelhető Optional Open Article (www.oopenart.com).

Adott dij ellenében az online közlemények bárki számára hozzáférhetök honlapunkon (a közlemények külön linket kapnak, így más oldalról is linkelhetővé válnak).

Bővebb információ a hirdetes@akkrt.hu címen vagy különlenyomat rendelése esetén a Szerkesztőségtöl kérhető. 